\title{
RE-STRATEGY OF CHARACTER EDUCATION OF NAVAL ACADEMY (AAL) CADETS IN ORDER TO STRENGTHEN NATIONAL RESILIENCE
}

\author{
Supriady Ferry ${ }^{\star}$, Fadli Mohammad \\ University of Brawijaya, Malang, Indonesia \\ *E-mail: supriadyferry110@gmail.com
}

\begin{abstract}
Character building is very important for the Indonesian people in order to give birth to a strong nation generation. The Naval Academy (AAL) is a boarding school where all of its cadets live and study in dormitories whose full education, both academic, skills and character attitudes are all obtained from AAL. The problem is that some concepts about character have been running, but currently the study load (SKS) of character education has not been accommodated in the curriculum which tends to be concentrated on the formation of professionalism, this results in a stagnant and not dynamic educational processthus causing the phenomenon of a decrease in military attitudes and mental struggle in the cadets, thus causing an effect on the development of the Indonesian Navy's human resources. The purpose of this paper is to redesign the future development of character education for AAL cadets. By using qualitative methods can produce a more comprehensive phenomenon.
\end{abstract}

\section{KEY WORDS}

Strategy, character education, AAL cadets, national resilience.

With the development of science and technology, the current conventional war between countries is very small. At this time many countries have started to switch to new types of war including asymmetric war (Asymmetric Warfare), Hybird War and Proxy War ${ }^{1}$. Currently the world has entered the era of the industrial revolution 4.0, indirectly this has a positive and negative influence on society. The era of education which is influenced by the industrial revolution 4.0 can be seen from the use of digital technology so that it is able to make the learning process take place continuously without knowing the boundaries of space and without knowing time limits. Education as the most strategic institution in guarding the millennial generation is required to be able to equip students with competencies that are not only in the form of hard skills, but also soft skills.

The deterioration of character education will have an impact on the mental deterioration of the nation in various levels of society, government and private institutions including the Indonesian Armed Force (TNI), which can result in the destruction of the nation and the Unitary State of the Republic of Indonesia (NKRI). Since the reformation, the character of TNI soldiers as the People's Army, the Warrior Army and the National Army seems to have been eliminated, or deleted. TNI soldiers seem to be only required for their professional character. As a result, TNI soldiers seem to drift away from understanding to improve their professionalism ${ }^{2}$. The character of struggle and maintaining the unity and integrity of the nation seems to be forgotten and thrown away. As a result, ethno-nationalism or narrow nationalism based on ethnicity, religion, race and class or nationalism based on SARA in various components of the nation thrives. TNI soldiers who actually have the character of fighters, nationalistic and militant with the pioneers that have been carried out, seem to only be spectators in the midst of the hustle and bustle of the noise of democracy which is colored by various social conflicts. Such conditions need to be addressed with the concept of adequate national vigilance so that social disintegration does not continue to become national disintegration. There are still violations by TNI Soldiers that occur at this time indicating that character building needs to be further strengthened. Based on data from the

\footnotetext{
${ }^{1}$ Gatot Nurmantyo, Penjabaran perang asimetris (Asymmetric Warfare), perang hibrida (Hybird War) dan perang proxy (Proxy War). Fajar.CO.ID Jakarta.

${ }^{2}$ Arifuddin Uksan, Pendidikan Karakter TNI Dalam MenghadapiTantangan Globalisasi, (Jakarta, 2017).
} 
TNI Military Police Center (Puspom TNI) from 2014 to 2016, in 2014 there were 1,800 cases of violations, in 2015 there were 2,269 cases and in 2016 there were 1,807 cases. These figures show that the violations are classified as high and require fast and appropriate handling through character strengthening ${ }^{3}$.

In order to reduce the moral crisis that is happening in our country, it is necessary to strengthen character education, which is currently a very worrying condition, especially what is happening in the community and family environment that involves children. The condition of this ethical and moral crisis indicates that the knowledge of ethics and morals obtained in education does not always have an impact on changes in Indonesian human behavior. With the facts surrounding the decline of character around us, it shows that there is a failure in our institutions in terms of growing Indonesian people with noble character or character. The urgency of character education is developed because one of the fields of national development that is very important and becomes the foundation of life in society, nation and state is the development of national character. There are several basic reasons behind the importance of building the nation's character, both philosophically, ideologically, normatively, historically and socioculturally.

In facing the development of a very dynamic situation like what happened in this era of globalization, it requires every TNI soldier to always understand and be aware of his values, character and identity, as the People's Army, Soldiers of Fighters, National Army and Professional Soldiers who uphold the Sapta Marga. , Soldier Oath and Eight Military Mandatory. The identity of the TNI is a reflection of the nature and character of the TNI which is a source of moral strength and TNI's dedication to the nation and state. TNI character education currently needs to be modernized, in line with the TNI reform concept that has been rolling since 1998 which has changed the pattern, professionalism and refunctionalization of the military in society. Facing the demands of the times, the TNI took an aspirational and accommodative attitude by formulating a new paradigm of its role and organizing itself by implementing internal changes, including in the field of education, namely the modernization of $\mathrm{TNI}$ character education, especially in facing the challenges of globalization.

Observing the problems faced and the demands of a very dynamic task faced with the complexity of the potential threats and developments of the existing 4.0 industrial revolution, it is necessary to improve the quality of human resources which is the key in increasing the progress of a country and nation. This is in line with the Government's programs and policies to continue the "Excellent HR, Advanced Indonesia" (SDM Unggul, Indonesia Maju) development program.

The Naval Academy (AAL) in implementing the education pattern does not only prioritize hard skills, but also soft skills. This was conveyed by the Minister of National Education, Mr. M. Nuh, namely the start of the national movement for character-based education in the new academic year 2011/2012 from Early Childhood Education (PAUD) to Higher Education ${ }^{4}$. AAL as a higher education institution in the form of a boarding school also participated in developing the concept of a character-based education system through the 2016 Indonesian Navy National Seminar with the theme "Development of a Character-Based Education Model for Indonesian Navy Soldiers".

Several concepts of character (Excellence, Professionalism, and Ethics) have been implemented in AAL but currently AAL only tends to lead to the formation of professionalism in Cadets, the lack of emphasis on ethical values has led to a decrease in military attitudes and mental struggle, based on data from the Directorate of Education AAL (Ditdik AAL) several violations of AAL cadets from 2016 to 2020, were considered to have greatly increased, especially in 2019 and 2020, these violations were categorized as an average violation of Ethics. Therefore, in AAL, it is necessary to develop an integrated pattern of character-based education, by starting to consider the factors that influence the process of

\footnotetext{
${ }^{3}$ Aspers Panglima TNI, Disampaikan pada Rakornis Bintal TNI, pada tanggal 20 Februari 2016, Cilangkap Mabes TNI.

${ }^{4}$ Muhammad. Nuh. (2011). Sambutan Menteri Pendidikan Nasional 2011.
} 
forming the character of the cadets to assessing the application of the characters that appear in the cadets when interacting both on campus and in the family and community.

The main step in this research proposal is to formulate the relationship between the variables of character development of AAL cadets, government policies and national security as well as appropriate and predictable strategies to strengthen national resilience. This is very important to do in order to support government policies by placing more emphasis on Human Resource Development and the Navy Chief of Staff Priority Program for Fiscal Year 2020 , one of the main priorities is the development of Indonesian Navy human resources in the context of developing the strength and capacity building of the Navy. The purpose of this research is to discuss the implementation of future character education development for AAL Bumimoro Surabaya cadets. By using qualitative methods that focus on in-depth observations that can produce a more comprehensive phenomenon.

Based on the explanation of the background described above, the problem to be formulated related to the Development of Character Education for AAL Cadets in the context of Strengthening National Resilience, can be formulated a problem statement or problem.

Several concepts about character, including Excellence, Professionalism, and Ethics, have been running at $A A L$, but currently the study load (SKS) of character education at $A A L$ has not been accommodated in the AAL curriculum which tends to be concentrated on the formation of professionalism, this results in a stagnant educational process and does not dynamic, thus causing a phenomenon of a decrease in military attitude and mental struggle in cadets which will have an effect on the development of human resources in the Navy as a whole and comprehensively which implies that the education process is not optimal.

So that the object of the writing is directed at reformulating the development of character education for AAL cadets in the face of Government policies and National Resilience, in accordance with the 1945 Constitution of the Republic of Indonesia Preamble (Preambule) 4th paragraph of the Government of the State of Indonesia which protects the entire Indonesian nation and all spills.

\section{RESULTS AND DISCUSSION}

AAL is the first educational institution at the academy level in the form of vocational training under the Chief of Naval Staff (Kasal) whose main task is to educate cadets to become Young Navy Officers (TNI AL) who have devotion to God Almighty and enthusiasm patriotism and the fighting spirit of Pancasila and the Sapta Marga based on the Soldier's Oath, 8 Mandatory TNI, Trisila TNI AL and upholding the motto Hree Dharma Shanty. In addition, cadets must have the latest knowledge and professional skills of sea-level soldiers within the scope of initial assignment on the Indonesian Warships (KRI) and battalions as Marine troops. Furthermore, they must also have managerial skills and leadership skills as future leaders of the TNI/TNI AL. The implementation of the AAL's main tasks is aligned with the achievement of the Indonesian Navy's vision, namely the realization of a reliable and respected Navy through the organization, systems, devices, as well as educational programs and processes ${ }^{5}$.

AAL is a university in the form of a boarding school, which is a boarding school with all its cadets living and studying in dormitories. With a pattern like this, education as a whole, both knowledge (academic), skills and attitudes (character) that are formed are all obtained at AAL. Because their activities are not only learning academic material, either theory or practice, but also how to behave in life with other friends, with AAL personnel ranging from members to top AAL officials, in this case it is necessary to habituate a good attitude as a provision for them to live in society.

Until now, AAL has succeeded in producing thousands of alumni who have been proven to be able to bring the Navy to its current condition. As the first educational institution at the officer level, AAL has received recognition for accreditation of study programs and

\footnotetext{
${ }^{5}$ Taufiqoerrachman, A. (2014). Akademi TNI Angkatan Laut Kelas Dunia. Surabaya: AAL, hal. 6.
} 
accreditation of higher education institutions by the National Accreditation Board for Higher Education (BAN PT) with satisfactory results, of course, this is the role of all of us without exception, and of course this we need to maintain and improve both the quality and feasibility of education so that the expected targets can be achieved as part of the effort to realize a world-class AAL (World Class Naval Academy).

The current condition of character education in AAL has existed for a long time, it's just that the pattern of parenting needs to be improved and the future curriculum revision must include character education in the curriculum in an integrated manner with teaching and training, so that the pattern of character-based education in AAL can form AAL graduate officers who high quality can be realized.

Several concepts about character (Excellence, Professionalism, and Ethics) have been implemented in AAL, however, Excellence, Professionalism, and Ethics at this time AAL only tends to lead to the formation of professionalism in Cadets, namely the pattern of education based on the development of science and technology. This results in an educational process that is stagnant or not dynamic. The lack of emphasis on ethical values causes a phenomenon where there is a decrease in military attitudes and mental struggles in cadets. This decline in military attitude and mental struggle will have an effect on the development of the Indonesian Navy's human resources as a whole and comprehensively, which has implications for the non-optimal educational process starting from character cultivation, professional development, and a continuous attitude to always give the best in the career path, especially in forming future Navy leaders have a great responsibility for the quality of their graduates. If the quality of graduates is high, the Navy in the future will experience a glorious period and vice versa. The Navy's vision to become a large, strong and professional Navy will be achieved, one of which is if AAL is able to produce high-quality graduates, both in terms of intellectual abilities, skills and character. Given that a person's character will color the pattern of attitudes, patterns of action and mindset of a person, such as John Dewey made moral philosophy as the basis in developing educational theories. The basic concept of moral education from Dewey is a moral judgment in the process as well as an assessment of practice.

"Moral philosophy is a fundamental part of Dewey's theory of education. Dewey, like Peirce and James, held that creative imagination, reflective thought, and action experimentation should be central features in education. In fact, the process of moral deliberation or judgment of practice is a core concept for Dewey's moral education." 6

Based on this concept, the conditions that are expected in the future need to develop an integrated pattern of character-based education, by starting to consider the factors that influence the process of forming the character of cadets to assessing the application of characters that appear in cadets both on campus and in families and communities. and the study load (SKS) of character education at AAL can be accommodated in the curriculum.

This writing requires a qualitative method defined by Creswell $^{7}$ as a process of gaining an understanding based on a tradition of inquiry with a distinguishable methodology, exploring a social or human problem in which the researcher constructs a complex, holistic picture, analyzes words, reports detailed views of the information, and conducts research under conditions natural. Meanwhile, according to Strauss and Corbin ${ }^{8}$, Qualitative research is any type of research that produces findings that are not obtained using statistical procedures or other quantification tools and such research can refer to the lives, stories, behavior of people, as well as about the functioning of organizations, social movements or interactional relationships. The three main components of a qualitative method are:

- Data, usually obtained by using interviews and observation;

\footnotetext{
${ }^{6}$ See James Arthur, "Traditional Approaches to Character Education in Britain and America," in Handbook of Moral and Character Education, ed. Larry P. Nucci and Darcia Narvaez, 80-98 (New York: Routledge, 2008); and John Snarey and Peter Samuelson, "Moral Education in the Cognitive Developmental Tradition: Lawrence Kohlberg's Revolutionary idea," in Handbook of Moral and Character Education, ed. Larry P. Nucci and Darcia Narvaez, 61-83 (New York: Routledge, 2008).

7 John W. Creswell, "Research Design Qualitative, Quantitative and Miixed Methodes Approach (Calofornia, 2009).

${ }^{8}$ Strauss A. and Juliet Corbin. Dasar-dasar penelitian kualitatif, tata langkah dan Teknik-teknik teorisasi data (Terjemahan) (Jogjakarta: Penerbit Pustaka Pelajar. 2009).
} 
- Interpretive or analytical procedures used to obtain findings or theories. This procedure is a technique for conceptualizing data which is known as coding. These procedures vary depending on the knowledge, experience and goals of the researcher;

- Verbal and written reports that can be presented in scientific journals.

Strauss and Corbin distinguish the types of qualitative research based on the research objectives, data analysis approach and research type. Based on research objectives, for example to clarify and illustrate quantitative findings, develop research instruments, develop policies, evaluate programs, provide information for commercial purposes, direct practitioners' practices, serve political goals and develop basic knowledge. Based on the data analysis approach, qualitative research is divided into 3 types, namely qualitative research with data that is not analyzed and accepted as is without or with very little interpretation; qualitative research with descriptive analysis data (selection and interpretation) accurately with a view to reducing data, as well as qualitative research intended to build theory, namely the development of theoretically explained interpretations. From all these approaches, a model is needed that can describe the process data comprehensively so that it is possible to conduct process analysis of the phenomenon under study more accurately. However, describing a social process into a comprehensive model so that it can be analyzed easily is not an easy task.

The object of this writing is directed at the development of character education for AAL cadets faced with government policies regarding national resilience by using a method that is an approach that can solve and explain the root problems that arise in the AAL cadet character development activities using SSM. With the human activity system model, it is possible to describe the principles, rules and relationships between parties within the AAL environment. With the design of the soft system and hard system models for character education at $A A L$, the ongoing process of developing character education for AAL cadets can clearly detect problematic situations and solutions for handling them. The objects, concepts and methods of this research have partially been used by researchers and scientists before, however, simultaneous and integrated use has never been done, and both in terms of AAL cadets character education, Government Policy and National Resilience.

In detail the originality and novelty presented in the writing are as follows:

- Modeling is in the form of additional theoretical input and reconstructing concepts and theories by several previous experts which will be discussed in this study;

- Model development using SSM, as a tool in problem analysis.

Furthermore, this Conceptual Framework of Writing was compiled, which is a basic model formulated from the basis of the above theories and combined with empirical conditions. This writing is classified in conclusive research, namely specific research with a clear purpose the results can directly and tangiblely provide information and contributions, then this research belongs to the category of causal research because this research seeks to explain the causal relationship between variables in the research model ${ }^{9}$.

Results in data processing using SSM data analyst techniques, is a methodology approach to solve complex problem situations that are not structured based on holistic conditions and system thinking that focuses on creating a system of activities and human relationships in the organization to achieve common goals. According to Checkland and Poulter Soft Systems Methodology ${ }^{10}$ is the process of finding out action-oriented problems from everyday real life and as a tool to model the process so that the phenomena studied can be analyzed in a more structured, comprehensive and holistic.

The cycle in the SSM process consists of seven stages of activities grouped into two domains, namely the real world realm and the realm of system-all thinking about the real world. The seven stages of SSM are ${ }^{11}$ :

\footnotetext{
${ }_{9}^{9}$ Kinnear, Thomas C, Dan Taylor, James R., (1995). Riset Pemasaran, Edisi Tiga, Jakarta: Erlangga

${ }_{11}^{10}$ Hardjosoekarto, Soft System Methodology, 60

${ }^{11}$ Ibid, 63-66
} 
Phase 1, Understanding problematic situations, in this stage, is the process of determining real-world situations that are considered problematic. Because generally the problems have to be solved more than one so it needs identification one by one.

Phase 2, Describing the problem situation (Problem Situation Expressed), the pouring stage of the problem situation that is considered problematic into the form of presentation of rich picture Collecting data and information with observations, interviews, workshops and discussions followed by formulation and presentation of these problems.

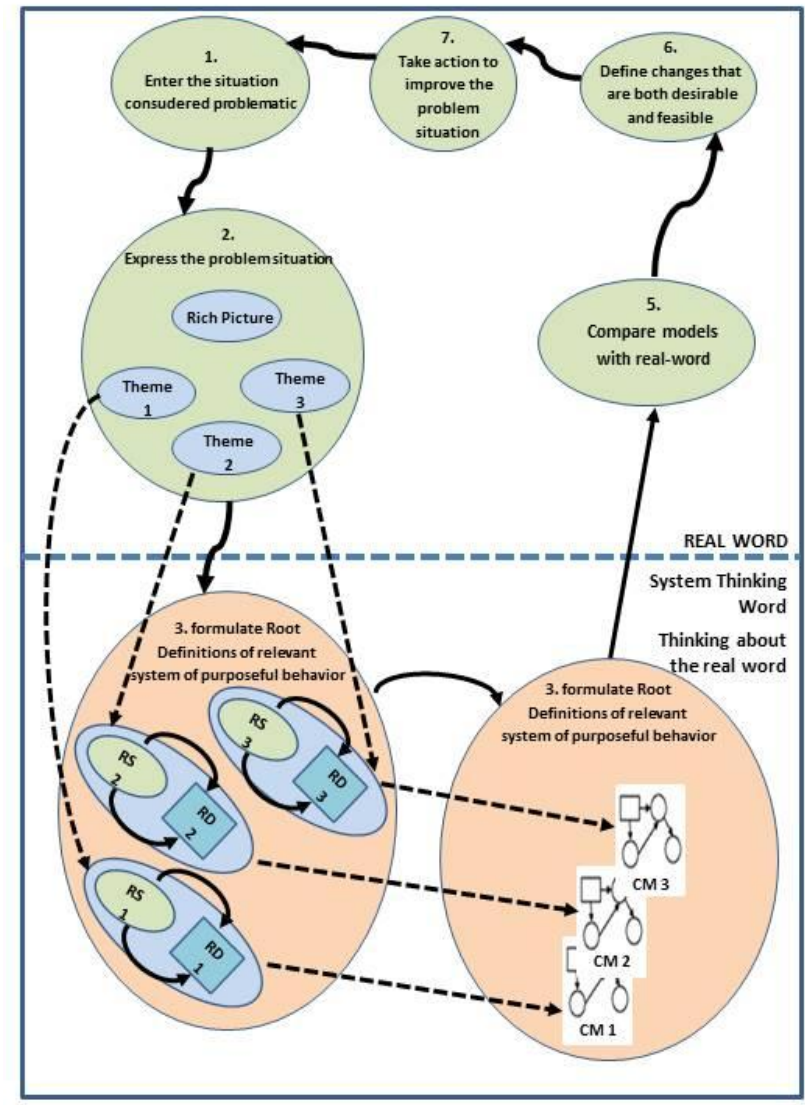

Figure 1 - Seven Step Soft Systems Methodology (SSM) by Peter Checkland (Source: Overview of the Soft Systems Methodology, 2015)

Phase 3, Determining the Root Definitions of Relevant purposeful activity Systems, Identifying the organizations involved, transformations/ processes, perspectives and environments then build the difinis human activity system needed to improve the problem situation. In root definition is illustrated what (what), how (how), and why (why) related to the transformation process / process to achieve the goal. to test the root definitions by analyzing Customers, Actors, Tranformation, Worldview, Owners, Environment (CATWOE).

Phase 4, model development (Conceptual Models), in this stage based on root definition for each element identified then build the conceptual model needed to achieve the ideal goal, the model is described by activity model, which is followed by determining and measuring the performance of the model (efficacy, efficiency \&effectiveness).

Stage 5, Comparisons of models and Real worlds, the comparison stage between conceptual models and reality and usually formulations will appear, but also manage discussions about real-world situations so that it is possible to emerge various points of view that have been hidden.

Phase 6, Make the desired and systematic changes (Define Changes), the stage of formulation of action suggestions for improvement, improvement, and change of the realworld situation. it is not always necessary to apply changes in the solution. If this is the case, then this change should be determined and checked whether it is feasible or not. 
Phase 7, Take action to improve the situation, action to improve the situation, correct, improve and change the problematic situation, important steps to take action in fixing problematic situations. Changes from step 6 will take effect in the organization. If the problem occurs, the cycle starts again at the first stage. Thus, SSM has a repeating cycle.

CATWOE analysis is a reminder (mnemotic) that the root definition made really describes a system of relevant human activity, the steps of which include ${ }^{12}$ :

- C: Customers. People or groups of people who are directly victimized or benefited in the process of organizational transformation;

- A: Actors. People or groups of people who are transforming;

- T: Transformation. The process of converting inputs into outputs, both concrete and abstract;

- W: Weltanschauung/World view. A way of view that makes transformation meaningful;

- O: Owners. A responsible person or group of people who can stop the transformation;

- E: Environment. The environment that is an obstacle to the transformation process, such as legislation, budget and other resources.

SSM is used to analyze data implemented in seven stages. The first stage of SSM, examinations of the problem situation have been described in the description of the research background in the Introductory Chapter, while the second to seventh stage will be explained in data analysis and discussion. The second stage of SSM is to create a Rich Picture that serves to provide a general picture of the results of data retrieval on the problem, the selection of a whole or large image. Rich Picture explains comprehensively starting from the formulation of problems where previously research problems are described and can be seen complexity up to the results of research and interpretation of data.

Based on the reference from Peter Checkland compiled in the making of Rich Picture begins by doing three stages of analysis, namely Analysis One (Intervention), Analysis Two (Social), and Analysis Three (Politics). At this stage will be analyzed aspects that influence research with intervention analysis, social analysis and political analysis to obtain Rich Picture. Here's a description of the three analyses in the study.

Analysis One (Intervention). Analysis One is the first stage in understanding the problem situation in the study. At this stage determine the instrument or related party to the situation or problem. According to Peter Checkland there are three categories of parties related to research issues, namely Client or client, Practitioners or practitioners, and Owner or owner of the issue.

1. Clients $(\mathrm{C})$ :

Clients are parties who have a role to intervene directly to the research conducted. Clients (C) of this study are Researchers/Authors and Advisors I and Advisors II.

2. Practitioner $(\mathrm{P})$ :

Practitioners are parties who conduct studies or research using SSM, In this study (P) is a Researcher / author. Practitioners also intervene in data processing and data classifying so that it can be poured into Rich Picture.

3. Owners $(\mathrm{O})$ :

Owners are the owners of the issue in the context of this research, owners are parties who have interests and are affected by research problems. In this study $(O)$ is an instrument involved either as a regulator or operator, that is; Staff personnel of TNI Headquarters (Spers Mabes TNI), Personnel Staff of THE NAVY Headquarters (Spers Mabesal), Naval Education Office (Disdikal) and Administration and Naval Personnel Service (Disminpersal).

Analysis Two (Social).

1. Role Elements:

Roles are social positions that distinguish authority and responsibility between actors in this study. To be able to determine the role element in a study, it must be able to formulate in advance who are the actors involved in this research. Previously mentioned that the Owners of this study are Staff Personnel Headquarters TNI (Spers Mabes TNI), Personnel Staff

\footnotetext{
12 Ibid, 63-66
} 
Headquarters TNI AL (Spers Mabesal), Naval Education Service (Disdikal) and The Administrative and Personnel Office of the Navy (Disminpersal). The categories created based on the role in the context of this study are; regulator operators, and observers. Each role group has different tasks and responsibilities in the context of research.

2. Norm Elements:

Elements of the norm at the SSM stage to explain how the criteria, according to the standards specified to the role and behavior according to the role. The norm intended in this writing is all written or unwritten rules or guidelines on how Staff Help III Spers Mabes TNI, Staff Help III Education Spers Mabesal, Disdikal and AAL in carrying out cooperation Restrategi Character Education Development AAL Cadets.

3. Values Elements:

The value element in the research is the correctness aspect of all research information involved as well as how it is implementing in the field. The intended value is to refer to the cooperation of changing an AAL education policy.

Analysis of the Three (Politics). Political analysis is believed to determine what should and should not be done. Political analysis will analyze the power structure of a situation and determine how to deal with it. This analysis is a discussion of the disposition of power and nature of power discussed from each institution related to the research of regulators, operators, and observers in this study.

Rich Picture. In the Rich picture stage is a picture of the previous SSM stage and the results of the researcher's data collection to the informant are poured in the form of images and statements. Rich picture aims to provide a comprehensive picture of the problems and results of research. In the following rich picture can be seen how the views of each informant related to the research issue discussed, namely the cooperation of character education development strategy for cadets of the Naval Academy.

Root Definition. In the third step the SSM step is Root definition. In this study, Root definition will be formulated in three questions which are presentations of research questions. That according to SSM theory, root definition using PQR formula is to answer the question Of What, Why, and How (What, Why, and How). Furthermore, the formulated root definition will be tested and refined with CATWOE analysis.

Identification with CATWOE analysis is the basis for the preparation of conceptual models that will be created later. Furthermore, the results of CATWOE set will be further analyzed with criteria 3E (Efficacy, Efficiency and Effectiveness) to measure the performance of the activity system, as follows:

- Efficacy (whether the transformation process can really realize the desired results);

- Efficiency (whether it can be efficient/with the use of semi-reliable resources);

- Effectiveness (whether it can help achieve long-term goals in the PQR formula).

Table 1 - CATWOE Analysis

C Chief of naval staff as AAL User alumni

A Governor of AAL

T Implementation of Character Development Concept of AAL Directors

W Regiment commander as the executor of the care.

O Chief of naval staff

E Director of Education as a Conceptor of Character Education Development

Source: Research Analysis (2021, processed).

Table 2 - 3E Analysis

\begin{tabular}{|l|l|}
\hline Efficacy & $\begin{array}{l}\text { Navy Chief of Staff Must Emphasize Character Building on Cadets and Cadets In Accordance with } \\
\text { Sea Matra Soldiers }\end{array}$ \\
\hline Efficiency & All Civitas Naval Academy \\
\hline Effectiveness & Implementation of The Formation of Sea Matra Character as the Main Goa \\
\hline
\end{tabular}

Source: Analysis results (2021). 
In the fourth stage of SSM is to form a conceptual model by connecting all activities that will be carried out in order to perform the T process (in the CATWOE analysis table), so that it becomes a complete system. This step is done by combining all the steps that have been done in the third stage or root definition in determining the relevant system for use in solving research problems are as follows:

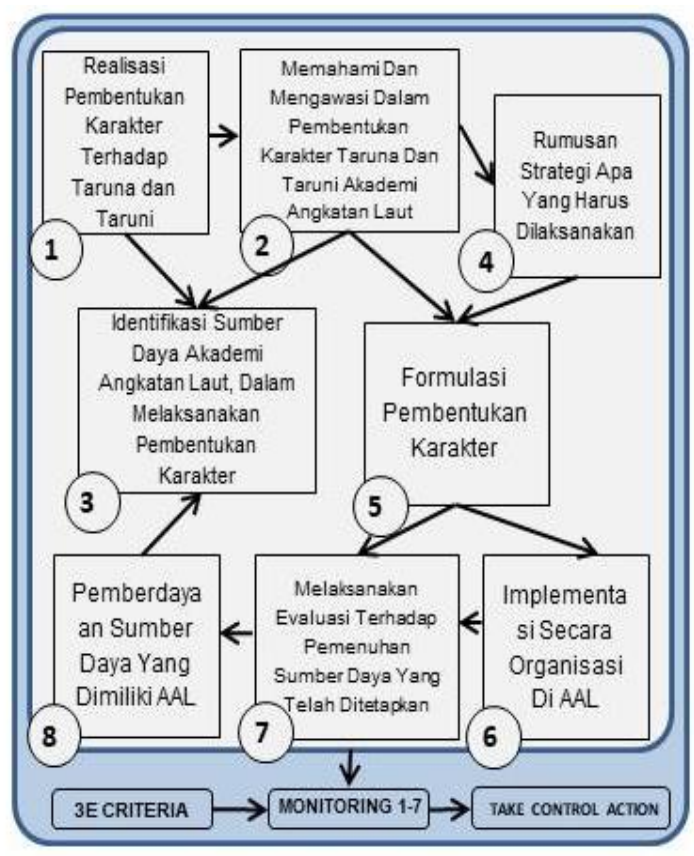

Figure 2 - Conceptual Model and Root Activity definition. Source: Research Analysis (2021, processed)

System Thingking Character Formation Cadet AAL. The system of thinking in the development of character development controlling AAL in order to support national resilience in this study was formulated in three questions representing question research. Discussion of root definitions using the PQR formula to answer the question of what, why, and how (what, why, and how), the PQR formula in question is: "Do $P$, with (by) $Q$, to achieve (to achieve) $\mathrm{R}$ ". Recognizing that the degradation of character formation as a threat to the world of military education is very likely to come through a variety of sources that bring about a decrease in the process of character formation, in this case the Naval Academy. It is able to be implemented by: Understand that controlling the formation of the character requires adequate resources to support the produce of a soldier of the Navy who has character, Formulate what kind of resources will be formed in the Cadets and Cadets of the Naval Academy needed and identify what resources are needed in implementing the Navy Academy that is responsive, tanggon and trengginas, by meeting the three criteria that have been set in the organization, with steps: Fulfillment of human resources as a naval academy (P) wak, empowering the components of Lecturers and educators $A A L(Q)$, supporting the realization of National Resilience $(R)$.

Conceptual Character Development Model of AAL Cadets. The next stage of SSM is to form a conceptual model by connecting all the activities that will be done to perform the $T$ process (on the CATWOE analysis table) so that it becomes a complete system. This step is done by combining all the steps that have been done in the third stage or root definition in determining the relevant system to be used in solving research problems, namely by: Fulfillment of human resources as a guardian of the Naval Academy $(P)$, empowering the components of Lecturers and educators $A A L(Q)$, supporting the realization of National Resilience (R).

Fulfillment of Human Resources (HR) of the Naval Academy (P) by: 
- The list of unfilled Personnel Arrangements (DSP) must be filled in accordance with the decision of the organization of procedures set by Kasal;

- Selection with competency model of each naval academy, according to the required field;

- Improved standardization of human resources competencies that exist today in AAL. Empowering the components of Lecturers and Educators AAL (Q), by:

- Standardization of Lecturers and Educators in implementing the teaching, training and nurturing process (Jarlatsuh);

- Standardization of Lecturers in accordance with the rules of the Ministry of Higher Education, so that each Lecturer only focuses on teaching cadets;

- Lecturers must carry out Tri Dharma of Higher Education in the form of Teaching, Research and Community Service.

Supporting the realization of National Resilience $(R)$, by:

- Developing the Character of Cadets by continuing to implement Kartika Jala Krida (KJK) Domestically in the Border Region of the Country, either sea or land;

- Developing the Character of Cadets by knowing Domestic and Foreign Cultures, in order to understand the embodiment of the State of Indonesia with a variety of cultures;

- Developing Training Exercises on Ships as Sea Matra Soldiers to develop Marine Character.

Table 3 - Gap analysis of gap questions

\begin{tabular}{|l|l|l|}
\hline No & Gap & Analysis \\
\hline 1 & Identification of Character Education Development implementation & $\begin{array}{l}\text { Ferry theory } \\
\text { Interview Results }\end{array}$ \\
\hline 2 & Development of Current Cadet Character Education & $\begin{array}{l}\text { Interview Results } \\
\text { Previous research }\end{array}$ \\
\hline 3 & Evaluation of Cadet Character Education Development & Interview result \\
\hline
\end{tabular}

AAL Cadet Character Building Strategy. In order to carry out the character development of Taruna AAL, there are several strategies that must be implemented. The strategy can be implemented with End, Mean and Way ${ }^{13}$, by:

- Carrying out identification of the implementation of Character development by comparing between theory and reality against the Character of Cadets and cadets of the Naval Academy;

- Reducing data and drawing a penciled-in conclusion from resource persons;

- Evaluating directly on the character development of Naval Academy Cadets.

\section{CONCLUSION}

Character education in AAL has existed since long ago as a college in the form of Boarding School only needs to be improved parenting patterns. In revising the upcoming curriculum should include character education in the curriculum integrated with teaching and training, starting from the form of Program Plan P as the format above. Factors that affect the education of cadet character can not be separated from the 10 components of education, which are then analyzed based on external factors and internal factors.

Effective strategies in educating Cadets to have good character there are several strategies, namely with the main strategy of designing character-based education patterns in $A A L$ and include in the curriculum, integrated between teaching, training and parenting. Character-based education patterns in AAL in order to form AAL graduate officers who can form and prepare future Navy Officers who are professional, moral, have a high level of discipline, dedication and loyalty in carrying out their duties.

\footnotetext{
${ }^{13}$ Henry E. Eccles, "Logistics in the National Defenc"(Pennsylvania:The Stackpole Company Harrisburg, 1959).
} 


\section{REFERENCES}

1. Akademi Angkatan Laut. Naskah Sementara Buku Petunjuk Pelaksanaan Pengasuhan Taruna AAL. Akademi Angkatan Laut, Surabaya: 2016.

2. Arthur, J. The Re-emergence of Character Education in British Education Policy. British Journal of Educational Studies: Values, Ethics, and Character in Education, Vol. 53, 3, pp. 239-254. 2005.

3. Budhiman, A. Dr. Pengembangan Model Pendidikan Berbasis Karakter bagi Prajurit TNI AL. Surabaya: Presentasi Seminar Nasional TNI AL 2016 dalam rangka Hari Pendidikan TNI AL ke-70.

4. Creswell, "Research Design Qualitative, Quantitative and Miixed Methodes Approach. (California, 2009)

5. Eccles, Henry E, "Logistics in The National Defence". (Pennsylvania: The Stackpole Company Harrisburg, 1959).

6. Dimyati dan Mudjiono, Belajar dan Pembelajaran, Rineka Cipta, Jakarta: 2013

7. Hardjosoekarto, Soft System Methodology, Jakarta: 2017.

8. Kartono, K. \& Gulo, D. Kamus Psikologi. Pionir Jaya. Bandung: 1987.

9. Kinnear, Thomas C, Dan Taylor, James R., (1995). Riset Pemasaran, Edisi Tiga, Jakarta: Erlangga.

10. Kementerian Pendidikan Nasional. Panduan Pelaksanaan Pendidikan Karakter.Pusat Kurikulum dan Perbukuan Badan Penelitian dan Pengembangan Kementerian Pendidikan Nasional. Jakarta: 2011.

11. Kertajaya, H. Pendidikan Karakter. Gramedia, Jakarta: 2010

12. Lickona, T. Education for Character: How Our School Can Teach Respect and Responsibility. The Phi Delta Kappan, Vol. 81, 1, pp. 26-27. 1991.

13. Marsetio, Dr. TNI Angkatan Laut Kelas Dunia: Paradigma Baru. Markas Besar Angkatan Laut. Jakarta: 2014.

14. Nuh, M., Desain Induk Pendidikan Karakter.Kementerian Pendidikan Nasional. Jakarta: 2010.

15. Nurmantyo G Penjabaran perang asimetris (Asymmetric Warfare), perang hibrida (Hybird War) dan perang proxy (Proxy War). Fajar.CO.ID Jakarta

16. Peraturan Menteri Pendidikan dan Kebudayaan Republik Indonesia Nomor 23. 2015. Penumbuhan Budi Pekerti.

17. Rangkuti, Freddy. Analisis SWOT Teknik Membedah Kasus Bisnis. PT Gramedia Pustaka Utama, Jakarta: 2003.

18. Snedden, D. (1918, August 8). The Improvement of Character Education. The Journal of Education, Vol. 88, 6, pp. 144-145.

19. Strauss A. and Juliet Corbin. Dasar-dasar penelitian kualitatif, tata langkah dan Teknikteknik teorisasi data (Terjemahan) (Jogjakarta: Penerbit Pustaka Pelajar. 2009)

20. Suyanto, S, Implementasi Pendidikan Karakter melalui Pembelajaran Terpadu. 2009.

21. See James Arthur, "Traditional Approaches to Character Education in Britain and America," in Handbook of Moral and Character Education, ed. Larry P. Nucci and Darcia Narvaez, 80-98 (New York: Routledge, 2008); and John Snarey and Peter Samuelson, "Moral Education in the Cognitive Developmental Tradition: Lawrence Kohlberg's Revolutionary idea," in Handbook of Moral and Character Education, ed. Larry P. Nucci and Darcia Narvaez, 61-83 (New York: Routledge, 2008).

22. Taufiqoerrachman, A, Akademi TNI Angkatan Laut Kelas Dunia. Akademi Angkatan Laut, Surabaya: 2010.

23. Uksan Arifuddin, Pendidikan Karakter TNI Dalam Menghadapi Tantangan Globalisasi, (Jakarta: Sekolah Pascasarjana Universitas Islam Negeri (UIN)Syarif Hidayatullah,2017.

24. W. S. Winkel, Psikologi Pengajaran, Gadjah Mada University Press, Yogyakarta: 2004

25. Zohrabi, M., 2013. Mixed Method Research: Instruments, Validity, Reliability and Reporting Findings. Theory and Practice in Language Studies, pp. 254-256.

26. Undang-undang Republik Indonesia Nomor 20. Sistem Pendidikan Nasional, 2003. 